\title{
Amorphous silica nanoparticles trigger nitric oxide/peroxynitrite imbalance in human endothelial cells: inflammatory and cytotoxic effects
}

\author{
This article was published in the following Dove Press journal: \\ International Journal of Nanomedicine \\ 8 November 2011 \\ Number of times this article has been viewed
}

\section{J Jose Corbalan 1,2 \\ Carlos Medina' \\ Adam Jacoby ${ }^{2}$ \\ Tadeusz Malinski ${ }^{2}$ \\ Marek W Radomski' \\ 'School of Pharmacy and Pharmaceutical Sciences, Faculty of Health Sciences, Panoz Institute, Trinity College Dublin, Dublin, Ireland; ${ }^{2}$ Department of Chemistry and Biochemistry, Ohio University, Athens, $\mathrm{OH}$, USA}

Correspondence: Carlos Medina School of Pharmacy and Pharmaceutical Sciences, Faculty of Health Sciences, Panoz Institute, Trinity College Dublin, Dublin 2, Ireland

Tel +35 3I 8962823

$\mathrm{Fax}+35318963367$

Email carlos.medina@tcd.ie
Background: The purpose of this study was to investigate the mechanism of noxious effects of amorphous silica nanoparticles on human endothelial cells.

Methods: Nanoparticle uptake was examined by transmission electron microscopy. Electrochemical nanosensors were used to measure the nitric oxide (NO) and peroxynitrite $\left(\mathrm{ONOO}^{-}\right)$released by a single cell upon nanoparticle stimulation. The downstream inflammatory effects were measured by an enzyme-linked immunosorbent assay, real-time quantitative polymerase chain reaction, and flow cytometry, and cytotoxicity was measured by lactate dehydrogenase assay.

Results: We found that the silica nanoparticles penetrated the plasma membrane and rapidly stimulated release of cytoprotective $\mathrm{NO}$ and, to a greater extent, production of cytotoxic $\mathrm{ONOO}^{-}$. The low $[\mathrm{NO}] /\left[\mathrm{ONOO}^{-}\right]$ratio indicated increased nitroxidative/oxidative stress and correlated closely with endothelial inflammation and necrosis. This imbalance was associated with nuclear factor $\kappa \mathrm{B}$ activation, upregulation of key inflammatory factors, and cell death. These effects were observed in a nanoparticle size-dependent and concentration-dependent manner.

Conclusion: The $[\mathrm{NO}] /\left[\mathrm{ONOO}^{-}\right]$imbalance induced by amorphous silica nanoparticles indicates a potentially deleterious effect of silica nanoparticles on vascular endothelium.

Keywords: amorphous silica nanoparticles, nanotoxicology, nitric oxide, peroxynitrite, inflammation, risk factors

\section{Introduction}

The use of synthetic amorphous silicon dioxide or silica nanoparticles in medicine is becoming increasingly accepted for a variety of therapeutic, diagnostic, and imaging applications. ${ }^{1,2}$ This adds to the already significant industrial exposure to silica nanoparticles during production, storage, transportation, and consumer use. ${ }^{3}$ It is increasingly recognized that amorphous silica nanoparticles induce cytotoxicity. ${ }^{4}$ However, genotoxicity induced by amorphous silica nanoparticles seems to be cell-line dependent. ${ }^{5-7}$ Overall, little is known about the toxicological effects of nanoparticles on the vasculature.

This study elucidates a direct interaction between engineered amorphous silica nanoparticles $(10 \mathrm{~nm}, 10 \mathrm{SiNP} ; 50 \mathrm{~nm}, 50 \mathrm{SiNP} ; 150 \mathrm{~nm}, 150 \operatorname{SiNP} ; 500 \mathrm{~nm}$, 500SiNP) and primary human umbilical vein endothelial cells (HUVECs). This cell line has been used as a reference for in vitro studies of endothelial cell function, since Jaffe et $\mathrm{al}^{8}$ developed a procedure to isolate them from the umbilical cord 
by collagenase digestion. Direct release of nitric oxide (NO) and peroxynitrite $\left(\mathrm{ONOO}^{-}\right)$during nanoparticle-cell interactions was measured by nanosensors. NO is essential for vascular homeostasis and disease. ${ }^{9}$ Endothelial cells and platelets generate NO which induces vasorelaxation, and with prostacyclin synergistically regulates vascular hemostasis by inhibiting platelet adhesion and aggregation. ${ }^{10-13}$ Impairment of NO bioavailability is one of the earliest events in vascular disease, ${ }^{9,14}$ and may result from decreased NO synthesis and/or increased superoxide $\left(\mathrm{O}_{2}{ }^{\bullet-}\right)$ generation. Superoxide reacts rapidly with $\mathrm{NO}$, producing $\mathrm{ONOO}^{-}$, a strong cytotoxic agent. ${ }^{15}$ High $\mathrm{ONOO}^{-}$production and depleted NO availability resulting in a low ratio $(<1.0)$ of maximal $\mathrm{NO}$ to maximal $\mathrm{ONOO}^{-}$concentrations $\left([\mathrm{NO}] /\left[\mathrm{ONOO}^{-}\right]\right)$can be used accurately as an indicator of nitroxidative/oxidative stress and endothelial dysfunction. ${ }^{16-18}$ It has been suggested that oxidative stress induces upregulation of gene expression by transcription factor activation. ${ }^{19}$ When activated, these factors initiate the transcription of several genes involved in inflammation and coagulation..$^{20,21}$ For instance, endothelial adhesion molecules, intercellular adhesion molecule 1 (ICAM1), ${ }^{22}$ vascular cell adhesion molecule 1 (VCAM1), ${ }^{23}$ and selectin E (SELE), ${ }^{24}$ provide cell-cell adhesion between the endothelium and leukocytes. Matrix metalloproteinase 9 (MMP9) ${ }^{25,26}$ digests various components of the extracellular matrix, such as type IV collagen, gelatin, and elastin, allowing leukocyte accommodation after diapedesis. Cyclooxygenase (COX) 2 mediates generation of COX-derived endothelium-derived constrictors and relaxants by converting arachidonic acid to prostaglandin $\mathrm{H}_{2} \cdot{ }^{20}$ Tissue factor (F3) is a key initiator of the coagulation cascade synthesized by endothelium in response to various stimuli. ${ }^{27}$ Interleukin 6 (IL6) has proatherogenic effects. ${ }^{28,29}$ Interleukin 8 (IL8) is involved in neutrophil chemotaxis and has proatherogenic and proinflammatory effects. ${ }^{29}$ Therefore, we studied the effects of amorphous silica nanoparticles on nitroxidative/ oxidative stress, inflammatory mediators, and cytotoxicity in primary HUVECs. Our results indicate that the [NO]/ $\left[\mathrm{ONOO}^{-}\right]$imbalance induced by silica nanoparticles may underpin the mechanism of cytotoxicity of amorphous silica nanoparticles in human endothelial cells.

\section{Materials and methods}

\section{Reagents}

All reagents were purchased from Sigma-Aldrich (Arklow, Ireland) unless indicated. Amorphous silica nanoparticles with different sizes (10SiNP, 50SiNP, 150SiNP, 500SiNP) were purchased from Polysciences (Eppelheim, Germany).

\section{Zeta potential measurement}

The zeta potentials of all the silica nanoparticles were determined by a Zetasizer Nano ZS (Malvern Instruments, Worcestershire, UK). Measurements were performed six times for each particle size $(100 \mu \mathrm{g} / \mathrm{mL}$ in ultrapure water) at room temperature.

\section{Transmission electron microscopy}

The nanoparticle suspensions $(10 \mu \mathrm{g} / \mathrm{mL}$ in ultrapure water) were examined using a JEM 2100 transmission electron microscope (JEOL, Hertfordshire, UK). The diameter of 100 nanoparticles of each size seen on three transmission electron micrographs was measured using Image $\mathrm{J}$, an open-source, Java-based imaging software (http://rsbweb. nih.gov/ij/). The shape of irregular nanoparticles was adjusted to a sphere before measurement.

\section{Cell culture}

Primary prescreened HUVECs were purchased from the Health Protection Agency Culture Collections (ECACC, Salisbury, UK). Cells were cultured in the recommended ECACC complete endothelial cell growth medium and maintained at $37^{\circ} \mathrm{C}$ in a $5 \% \mathrm{CO}_{2}$ humidified incubator. Cells were supplied with fresh medium every 2 days and propagated using the recommended ECACC subculture kit, for a maximum of 16 population doublings.

\section{Cell exposure to silica nanoparticles}

Primary HUVECs were exposed to amorphous silica nanoparticles suspended in basal media (ECACC complete media without serum or growth factors) supplemented with $2 \%$ fetal bovine serum and $0.03 \mathrm{mg} / \mathrm{mL}$ endothelial cell growth supplements. Immediately before use, commercial stock suspensions were sonicated for 2 minutes, and nanoparticle dispersions in culture media were prepared by serial dilution from these stock suspensions by vortexing. Controls were supplied with an equivalent volume of media without nanoparticles.

\section{Transmission electron microscopy of primary HUVECs}

The silica nanoparticle-endothelial cell interaction was studied by transmission electron microscopy. At $80 \%$ confluence, HUVECs seeded into $75 \mathrm{~cm}^{2}$ tissue culture flasks were incubated with $10 \mu \mathrm{g} / \mathrm{mL}$ 10SiNP for 1 hour. Thereafter, cells were collected in basal media and fixed by mixing with an equal volume of $3 \%$ glutaraldehyde in 0.05 $\mathrm{M}$ potassium phosphate buffer $(\mathrm{pH}$ 6.8) for 1.5 hours at 
room temperature. After primary fixation, samples were centrifuged and the pellets were washed six times with $0.05 \mathrm{M}$ potassium phosphate buffer ( $\mathrm{pH}$ 6.8). The pellets were then post-fixed with $2 \%$ osmium tetroxide in $0.05 \mathrm{M}$ potassium phosphate buffer ( $\mathrm{pH}$ 6.8) for 30 minutes. Pellets were then dehydrated in series of graded ethanol solutions, infiltrated, and embedded in agar 100 epoxy resin, using propylene oxide as a transitional fluid. Next, ultrathin sections were cut from dried blocks with a diatom diamond knife on an LKB Ultratom III (LKB, Uppsala, Sweden), stained with $0.5 \%$ aqueous uranyl acetate followed by Reynold's lead citrate. Finally, the sections were examined using a JEM 2100 transmission electron microscope.

\section{Measurement of $\mathrm{NO}$ and $\mathrm{ONOO}^{-}$ concentrations using nanosensors}

Concurrent $\mathrm{NO}$ and $\mathrm{ONOO}^{-}$measurements were performed with electrochemical nanosensors (diameter 300-500 nm). The designs were based on previously developed and well characterized chemically modified carbon fiber technology. ${ }^{30,31}$ Each of the sensors was made by depositing a sensing material on the tip of the carbon fiber, ie, a conductive film of polymeric nickel (II) tetrakis (3-methoxy-4hydroxy-phenyl) porphyrin for the NO sensor and a polymeric film of $\mathrm{Mn}$ (III)-paracyclophanyl-porphyrin for the $\mathrm{ONOO}^{-}$sensor. Amperometry was used to measure changes in $\mathrm{NO}$ and $\mathrm{ONOO}^{-}$concentrations from basal levels with time (detection limit of $1 \mathrm{nM}$ and resolution time $<10 \mu \mathrm{sec}$ for each sensor). Linear calibration curves were constructed for each sensor from $5 \mathrm{nM}$ to $3 \mu \mathrm{M}$ before and after measurements with aliquots of $\mathrm{NO}$ and $\mathrm{ONOO}^{-}$standard solutions. Nanosensors were positioned at $5 \pm 2 \mu \mathrm{m}$ from the cell membrane of a single endothelial cell. A calcium ionophore, A23187 (1 $\mu \mathrm{M})$, was used to stimulate the maximal release of $\mathrm{NO}$ and $\mathrm{ONOO}^{-}$from a single cell in the absence of nanoparticles.

\section{Fluorescence microscopy}

Primary HUVECs were plated into six-well plates. The next day, following 1 hour of incubation with 10SiNP $(10 \mu \mathrm{g} / \mathrm{mL})$, cells were incubated with 5-(and 6)-carboxy$2^{\prime}, 7^{\prime}$-difluorodihydrofluorescein diacetate (Invitrogen, Paisley, UK) in basal media for 30 minutes in a $37^{\circ} \mathrm{C}$, $5 \% \mathrm{CO}_{2}$ humidified incubator. A control in the absence of nanoparticles was also prepared. Adhesive cells were then washed twice with basal media and examined under an Axiovert $200 \mathrm{M}$ inverted fluorescence microscope (Carl Zeiss, Welwyn Garden City, UK) at $\lambda$ ex/ $\lambda$ em 485/530 nm.

\section{Measurement of NF- $\mathrm{KB}$ binding activity}

To evaluate the influence of silica nanoparticles on NF- $\kappa B$ binding activity, a specific enzyme-linked immunosorbent assay was performed on nuclear extracts from HUVECs (into $75 \mathrm{~cm}^{2}$ tissue culture flasks). Cells were exposed to 10SiNP $(10 \mu \mathrm{g} / \mathrm{mL})$ for 1 hour, and 50SiNP, 150SiNP, and $500 \operatorname{SiNP}(50 \mu \mathrm{g} / \mathrm{mL})$ for 3 hours. Controls in the absence of nanoparticles were also prepared.

\section{Purification of nuclear extracts}

Following incubation, nuclear proteins were isolated using a nuclear extraction kit (Cayman, Dublin, Ireland). The isolation was performed following the supplier's recommendations. Briefly, cells were washed once and then collected in a phosphate-buffered saline/phosphatase inhibitor solution. Cells were centrifuged and the pellets were washed twice with the same solution. The pellets were incubated for 15 minutes in a hypotonic buffer (containing both phosphatase and protease inhibitors) to allow the cells to swell. Nonidet ${ }^{\circledR}-\mathrm{P} 40$ assay reagent was then added to disturb the plasma membrane, and the samples were centrifuged. Pellets (nuclei) were incubated with a nuclear extraction buffer (containing both phosphatase and protease inhibitors) to disturb the nuclear membrane, and then centrifuged. Nuclear fractions, contained in the supernatants, were stored at $-80^{\circ} \mathrm{C}$. Protein concentration, in the nuclear extracts, was spectrometrically determined $(\lambda 595 \mathrm{~nm})$ by Bradford's method.

\section{Measurement of NF- $\kappa B$ (p65) DNA binding activity}

The binding activity of the p65 subunit of the transcription factor, NF- $\kappa B$, was assessed using a NF- $\kappa B$ (p65) transcription factor assay kit (Cayman). This enzyme-linked immunosorbent assay was performed following the supplier's recommendations. Briefly, nuclear fractions, containing $30 \mu \mathrm{g}$ of proteins were mixed with a binding buffer and then loaded into a duplicate set of wells in a 96-well plate. The wells hold a specific double-stranded DNA containing the $\mathrm{NF}-\kappa \mathrm{B}$ response element immobilized onto the bottom. Following overnight incubation, samples were washed five times and then incubated for 1 hour at room temperature with an anti-p65 antibody. Samples were further washed five times and then incubated for 1 hour at room temperature with a goat antirabbit horseradish peroxidase-conjugated antibody. Samples were again washed five times. A developing solution was added, and the plate was incubated for 15-45 minutes at room temperature with gentle agitation and protected from light. Following the addition of the stop solution, absorbance 


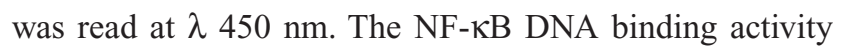
induced by each nanoparticle was expressed relative to the control sample. Further experiments were performed with silica nanoparticles only to rule out the possibility of particle interference in the assessment.

\section{Real-time quantitative polymerase chain reaction}

The effect of silica nanoparticles on the gene expression of key inflammatory factors was assessed by real-time quantitative polymerase chain reaction. Primary HUVECs (in six-well plates) were exposed to various concentrations of silica nanoparticles for 3, 7, and 15 hours. Controls in the absence of nanoparticles were also prepared. Following incubation, the cells were washed twice with phosphate-buffered saline. DNA-free RNA was isolated using an Ambion RNAqueous ${ }^{\circledR}$ 4PCR kit (Applied Biosystems, Warrington, UK) according to the supplier's recommendations. Thereafter, isolated RNA in each sample was quantified using a NanoDrop ${ }^{\circledR}$ ND-1000 spectrophotometer (Fisher Scientific, Dublin, Ireland). An equal quantity of total DNA-free RNA from each sample was reverse-transcribed using a high capacity cDNA reverse transcription kit (Applied Biosystems). Reverse transcription was performed using a Realplex ${ }^{2}$ Mastercycler (Eppendorf, Cambridge, UK). Finally, an equal quantity of total cDNA of each sample was used to performed real-time quantitative polymerase chain reaction in duplicate, with predesigned Applied Biosystems TaqMan ${ }^{\circledR}$ gene expression assays for ICAM1, VCAM1, SELE, MMP9, COX2, F3, IL6, and IL8, and Applied Biosystems TaqMan Universal PCR Master Mix; $18 \mathrm{~S}$ ribosomal ribonucleic acid (18S rRNA) was used as an internal control. Real-time quantitative polymerase chain reaction was performed using a Realplex ${ }^{2}$ Mastercycler. The expression of each gene, within each sample, was normalized against 18S rRNA expression and expressed relative to the control sample using the formula $2^{-(\Delta \Delta \mathrm{Ct})}$, in which $\Delta \Delta \mathrm{Ct}=(\mathrm{Ct}$ mRNA - Ct 18S rRNA) sample - (Ct mRNA - Ct 18S rRNA) control. ${ }^{32}$ Further experiments were performed with the silica nanoparticles only to rule out the possibility of nanoparticle interference with this technique.

\section{Lactacystin and real-time quantitative polymerase chain reaction}

Involvement of $\mathrm{NF}-\kappa \mathrm{B}$ in gene upregulation induced by silica nanoparticles was studied by real-time quantitative polymerase chain reaction. HUVECs (in six-well plates) were incubated with lactacystin $(1 \mu \mathrm{M})$ which suppresses $\mathrm{NF}-\kappa \mathrm{B}$ binding activity for 1 hour followed by exposure to
$10 \mu \mathrm{g} / \mathrm{mL}$ 10SiNP for 15 hours. Controls in the absence of nanoparticles and nanoparticle-treated samples in the absence of lactacystin were also prepared. After incubation, DNAfree RNA was isolated and real-time quantitative polymerase chain reaction was performed as above.

\section{Cytometric bead array}

A cytometric bead array human inflammatory cytokine kit (Becton Dickinson, Oxford, UK) was used to quantify IL6 and IL8 protein levels in the supernatants. Experiments were performed using a FACSArray ${ }^{\mathrm{TM}}$ bioanalyzer (Becton Dickinson). Cells (in six-well plates) were incubated with various concentrations of silica nanoparticles $(10,50$, 150 , and $500 \mathrm{~nm}$ ) for 15 hours. Controls in the absence of nanoparticles were also prepared. Assays were performed following the supplier's recommendations. Briefly, captured beads $(50 \mu \mathrm{L})$ coated with specific antibodies for the cytokines, supernatant samples $(50 \mu \mathrm{L})$, and phycoerythrin detection reagent $(50 \mu \mathrm{L})$ were mixed together and incubated at room temperature for 3 hours in the dark. Following washing, sample data were acquired by Becton Dickinson analysis software, and analyzed by FCAP Array ${ }^{\mathrm{TM}}$ software. The cytokine concentration was obtained using a calibration curve of human inflammation standards. Cytokine release induced by each nanoparticle was expressed relative to the control sample. Further experiments were performed with the silica nanoparticles only to rule out the possibility of nanoparticle interference with the technique.

\section{Assessment of toxicity}

To evaluate the cytotoxicity of the silica nanoparticles, HUVECs were seeded into 96-well round-bottom plates, and the lactate dehydrogenase (LDH) assay was performed. The activity of extracellular LDH release upon cell lysis was measured using a CytoTox $96^{\circledR}$ nonradioactive cytotoxicity assay (Promega, Southampton, UK). Cells were exposed to various concentrations of 10SiNP, 50SiNP, 150SiNP, and 500SiNP (LDHexp) in triplicate. The percentage of cell viability was determined $3,7,15$, and 30 hours post-treatment. Triplicate control wells in the absence of nanoparticles were also prepared (LDHcon). We also performed a positive LDH control supplied with the LDH assay to verify that the assay was functioning properly. Assays were performed following the supplier's recommendations. Briefly, after exposure of the cells to the nanoparticles, $50 \mu \mathrm{L}$ of the cell culture supernatants and $50 \mu \mathrm{L}$ of substrate mix were mixed together in a 96-well plate. Samples were incubated for 30 minutes in the dark. LDH activity was measured 
spectrophotometrically at $\lambda 492 \mathrm{~nm}$ following addition of a stop solution $(50 \mu \mathrm{L})$. A set of triplicate wells containing untreated controls was lyzed to extract the maximum $\mathrm{LDH}$ activity (LDHmax). A set of triplicate wells containing medium with neither nanoparticles nor cells was prepared (culture medium background). A set of triplicate wells was prepared to correct for volume changes caused by addition of lysis solution (volume correction control). The average of the absorbance values of the culture medium background was subtracted from the average of LDHcon and LDHexp. The average absorbance values for volume correction control was subtracted from LDHmax. Afterwards, the percentage of cell viability induced by each nanoparticle was expressed relative to the control sample according to the formula:

$$
\% \text { viability }=100-\left[\frac{(\text { LDHexp }- \text { LDHcon })}{(\text { LDHmax }- \text { LDHcon })} \times 100\right]
$$

\section{Statistical analysis}

All data are presented as the mean \pm standard error of the mean of $n>3$. Statistical analysis of the mean difference between multiple groups was determined by one-way analysis of variance followed by Tukey-Kramer multiple comparison tests, and between two groups by two-tailed Student's $t$-tests. The alpha level for all tests was 0.05 . A $P$ value $<0.05$ was considered to be statistically significant. All statistical analyses were performed using GraphPad Prism (v 5.00 for Windows; GraphPad Software, San Diego, CA) and Origin (v 6.1 for Windows; OriginLab, Northampton, MA).

\section{Results}

\section{Characterization of silica nanoparticles}

Accurate and careful physicochemical characterization of nanoparticles before assessing their in vitro toxicity is of crucial importance. ${ }^{33}$ As specified by the supplier, the commercially available negative surface-charged silica nanoparticles used in our studies (10SiNP, 50SiNP, $150 \mathrm{SiNP}$, and $500 \mathrm{SiNP}$ ) were uniform amorphous solid (nonporous) pure silicon dioxide made via a precipitation process. Our transmission electron microscopy studies showed that the larger particles (150SiNP and 500SiNP) had a spherical shape, while the shape of the smaller particles (10SiNP and 50SiNP) was more irregular (Figure 1A-D). Because significant deviations from nominal specifications are usual in commercially supplied samples, ${ }^{34}$ we used Image J software to measure particle diameter on transmission electron micrographs of nanoparticles to confirm the

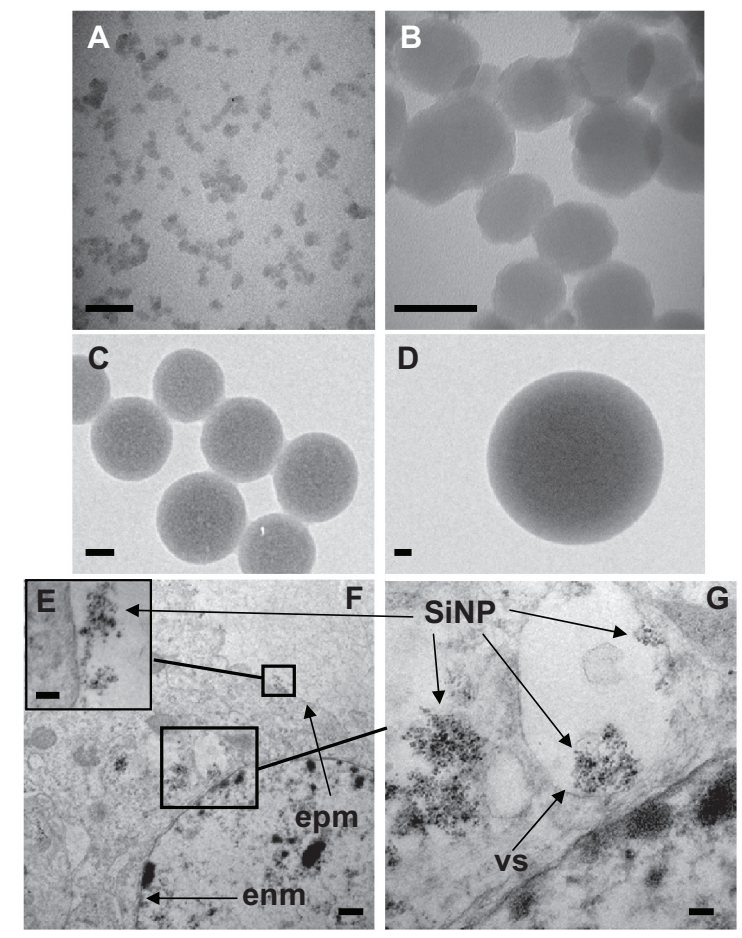

Figure I Uptake of amorphous SiNP by primary human umbilical vein endothelial cells. Electron micrographs of $\operatorname{IOSiNP}$ (A), 50SiNP (B), I50SiNP (C), and $500 \mathrm{SiNP}(\mathrm{D})$, in ultrapure water. As shown by transmission electron microscopy, after exposure of endothelial cells to $10 \mu \mathrm{g} / \mathrm{mL}$ of IOSiNP for I hour, nanoparticles quickly interacted with the plasma membrane, internalized, and distributed within the cytoplasm (E-G). They were found mainly encapsulated in vesicles, but also free in the cytosol (F and G). Scale bars represent $50 \mathrm{~nm}$ (A, B, C, and D), $100 \mathrm{~nm}$ (E and $\mathbf{G})$, and $500 \mathrm{~nm}(\mathbf{F})$.

Abbreviations: SiNP, silica nanoparticles; EPM, endothelial plasma membrane; ENM, endothelial nuclear membrane; VS, vesicle.

size specified by the vendor (Table 1). We also used a light scattering technique (Zetasizer) to measure the zeta potentials of the silica nanoparticles (Table 1). All the nanoparticles tested in our study had zeta potentials more negative than $-30 \mathrm{mV}$.

\section{Internalization of amorphous silica nanoparticles into HUVECs}

We performed transmission electron microscopy to study silica nanoparticle-endothelial cell interactions and uptake. After 1 hour of coincubation, we found that the amorphous silica nanoparticles $(10 \mu \mathrm{g} / \mathrm{mL}, 10 \mathrm{~nm})$ were taken up by primary HUVECs (Figure 1E-G). Indeed, the nanoparticles interacted quickly with the plasma membrane (Figure 1E and F), internalized, and distributed into the cytoplasm of the cells (Figure 1F and G). Moreover, the nanoparticles were found mainly encapsulated in vesicles. However, nonencapsulated nanoparticles were also observed. Furthermore, nanoparticles were observed forming agglomerates (Figure 1E-G). 
Table I Silica nanoparticle characterization. Nanoparticle properties (stock suspension concentration, size, surface charge, particles per milliliter, particles per gram, composition, synthesis, and porosity)

\begin{tabular}{|c|c|c|c|c|}
\hline & IOSiNP & 50SiNP & I50SiNP & 500SiNP \\
\hline Concentration $(\mathrm{mg} / \mathrm{mL}) *$ & 50.0 & 57.0 & 100.0 & 100.0 \\
\hline Size $(\mathrm{nm})^{*}$ & 10.0 & 50.0 & 150.0 & 500.0 \\
\hline Size $(\mathrm{nm})^{\dagger}$ & $10.50 \pm 0.19$ & $52.67 \pm 0.66$ & $148.20 \pm 2.19$ & $495.90 \pm 5.87$ \\
\hline Surface charge* & Negative & Negative & Negative & Negative \\
\hline Zeta potential $(\mathrm{mV})^{\#}$ & $-43.44 \pm 1.75$ & $-38.33 \pm 0.20$ & $-38.43 \pm 0.30$ & $-39.29 \pm 0.12$ \\
\hline Particles per $\mathrm{mL}^{*}$ & $4.90 \times 10^{16}$ & $3.92 \times 10^{14}$ & $2.99 \times 10^{13}$ & $7.42 \times 10^{\prime \prime}$ \\
\hline Particles per gram* & $9.55 \times 10^{17}$ & $7.64 \times 10^{15}$ & $2.83 \times 10^{14}$ & $7.20 \times 10^{12}$ \\
\hline Composition* & Pure $\mathrm{SiO}_{2}$ & Pure $\mathrm{SiO}_{2}$ & Pure $\mathrm{SiO}_{2}$ & Pure $\mathrm{SiO}_{2}$ \\
\hline Synthesis* & Precipitated & Precipitated & Precipitated & Precipitated \\
\hline Synthesis* & Colloidal & Colloidal & - & - \\
\hline Porosity* & Nonporous & Nonporous & Nonporous & Nonporous \\
\hline
\end{tabular}

Notes: *Supplied by the manufacturer, as well as re-evaluated by transmission electron microscopy (size) and by ${ }^{\#}$ Zetasizer (zeta potential) in ultrapure water.

Abbreviation: SiNP, silica nanoparticles.

\section{Imbalanced [NO]/[ONOO-] ratio in HUVECs causes nitroxidative/oxidative stress and endothelial dysfunction}

It has been suggested that nanoparticle-cell interactions may lead to oxidative stress and oxidant injury. ${ }^{35-37}$ Depleted NO and high $\mathrm{ONOO}^{-}$production by cells resulting in a low ratio $(<1.0)$ of maximal $\mathrm{NO}$ to maximal $\mathrm{ONOO}^{-}$concentrations have been used as an accurate indicator of oxidative stress leading to dysfunctional endothelium. ${ }^{16,18}$ Therefore, we studied in situ real-time dynamic interaction of the amorphous silica nanoparticles with primary HUVECs by measuring $\mathrm{NO}$ and $\mathrm{ONOO}^{-}$concentrations directly using nanosensors placed $5 \pm 2 \mu \mathrm{m}$ from the plasma membrane of a single cell. We demonstrated with time resolution better than 10 microseconds that these nanoparticles rapidly stimulated $\mathrm{NO}$ release, followed by $\mathrm{ONOO}^{-}$production after collision with cells (Figure 2A). The rate of NO production was in reverse proportion to nanoparticle size and directly proportional to particle concentration (Figure 2B). The silica nanoparticle-stimulated generation of cytoprotective and vasodilatory $\mathrm{NO}$ was followed by massive production of strongly oxidant and cytotoxic $\mathrm{ONOO}^{-}$, a major component of oxidative stress. When the nanoparticle concentrations were increased, a rapid exponential rate of $\mathrm{ONOO}^{-}$release from endothelial cells was observed for 10SiNP, and a sigmoid rate for 50SiNP (Figure 2C). The increase in rate of production of $\mathrm{ONOO}^{-}$with increasing concentrations was much the lower for larger nanoparticles (150SiNP and 500SiNP, Figure 2C). Exposure of endothelial cells to amorphous silica nanoparticles shifted the balance of maximal $[\mathrm{NO}] /\left[\mathrm{ONOO}^{-}\right]$unfavorably. Indeed, the smallest nanoparticles $(10 \mathrm{~nm})$ at $10 \mu \mathrm{g} / \mathrm{mL}$ significantly reduced the ratio of $[\mathrm{NO}] /\left[\mathrm{ONOO}^{-}\right]$for $5-6$ times as compared with the larger particles (Figure 2D). Moreover, the $[\mathrm{NO}] /\left[\mathrm{ONOO}^{-}\right]$ ratio was decreased in a size-dependent manner by an equal concentration $(100 \mu \mathrm{g} / \mathrm{mL})$ of 50SiNP, 150SiNP, and 500SiNP (Figure 2E). We obtained a maximal $[\mathrm{NO}] /\left[\mathrm{ONOO}^{-}\right]$ratio (higher than 2 ) upon stimulation of HUVECs with a calcium ionophore (A23187) in the absence of nanoparticles. The low $[\mathrm{NO}] /\left[\mathrm{ONOO}^{-}\right]$balance $(<1.0)$ derived from exposure of primary HUVECs to silica nanoparticles is indicative of high nitroxidative/ oxidative stress and endothelial dysfunction. This effect was of highest significance for nanoparticles smaller than $50 \mathrm{~nm}$.

In addition to our direct measurements with nanosensors, we also used fluorescence microscopy to verify indirectly the ability of amorphous silica nanoparticles to induce oxidative stress in treated endothelial cells (Figure 3). Moreover, the corresponding phase-contrast micrographs suggest cell death as a result of necrosis induced by silica nanoparticles, because HUVECs detached from the cell culture dish after particle exposure (Figure 3).

\section{Endothelial NF- $\kappa B$ activation and upregulation of inflammatory factors}

Because oxidative stress may lead to activation of transcription factors, ${ }^{19}$ we studied the effect of the amorphous silica nanoparticles on NF- $\mathrm{KB}$ DNA binding activity. We show that 10SiNP $(10 \mu \mathrm{g} / \mathrm{mL})$ induced increased endothelial NF- $\mathrm{\kappa B}$ activity after only 1 hour of exposure to cells, when compared with controls in the absence of nanoparticles. Furthermore, 50SiNP and 150SiNP $(50 \mu \mathrm{g} / \mathrm{mL})$ also increased transcription factor activity in 3 hours. In contrast, $500 \mathrm{SiNP}(50 \mu \mathrm{g} / \mathrm{mL})$ did not affect this activity in 3 hours (Figure 4). The endothelial NF- $\kappa B$ 

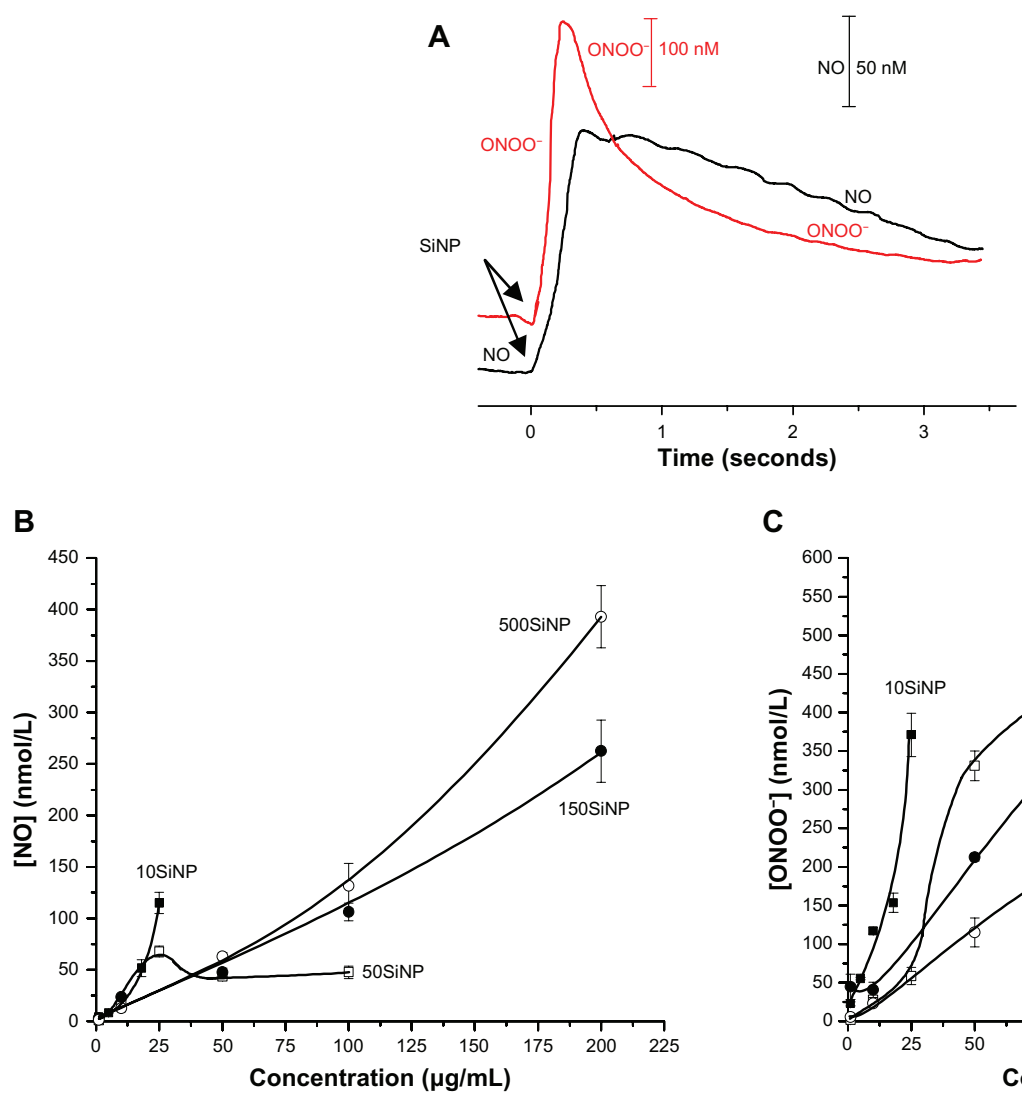

C
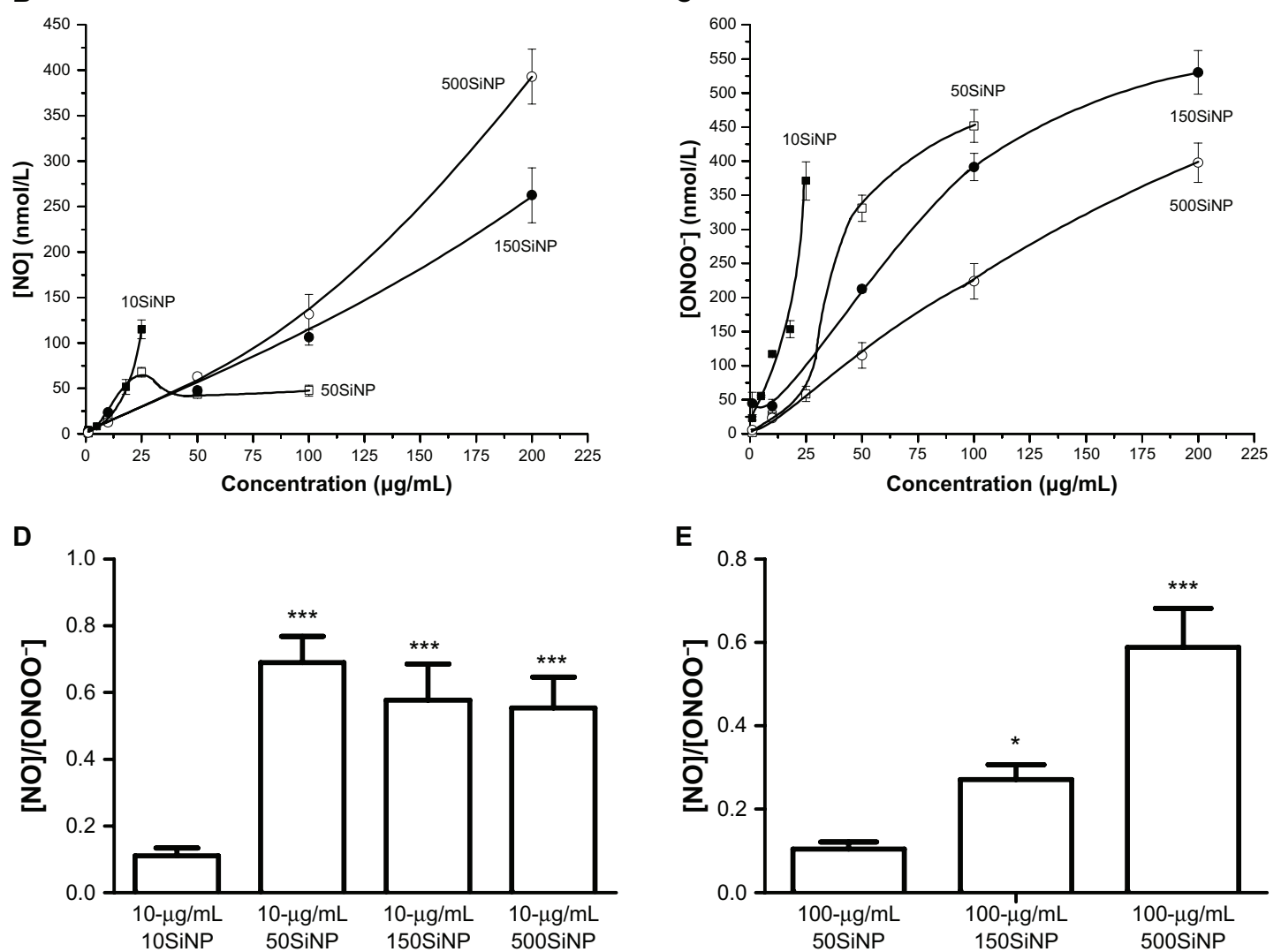

Figure 2 Amorphous SiNP induce $\mathrm{NO}$ and $\mathrm{ONOO}^{-}$production and unfavorably shift the [NO]/[ONOO-] balance in primary human umbilical vein endothelial cells. (A) Representative recordings of $\mathrm{NO}$ and $\mathrm{ONOO}^{-}$concentrations measured in situ by specific nanosensors placed $5 \pm 2 \mu \mathrm{m}$ for the surface of a single cell after addition of $25 \mu \mathrm{g} / \mathrm{mL}$ IOSiNP (arrows) to the cell culture media. Maximal concentration of NO (B) and ONOO- (C) released from cells following stimulation by I0SiNP ( $\mathbf{\square}$ ), $50 \mathrm{SiNP}$ $(\square)$, I50SiNP $(\bullet)$, and 500SiNP (O). All values are presented as the mean \pm standard error of the mean of $n=4$. One-way analysis of variance and Tukey-Kramer multiple comparison tests were used to analyze all sets of data. [NO]/[ONOO-] ratio of the maximal $\mathrm{NO}$ and $\mathrm{ONOO}^{-}$concentrations measured upon stimulation of cells by SiNP at $10 \mu \mathrm{g} / \mathrm{mL}$ (D) and at $100 \mu \mathrm{g} / \mathrm{mL}$ (E).

Notes: All values are presented as the mean \pm standard error of the mean of $n=4$. One-way analysis of variance, Tukey-Kramer multiple comparison test: $* P<0.05$, $* * * P<0.001$ compared with $10 \mu \mathrm{g} / \mathrm{mL}$ IOSiNP (D) and compared with $100 \mu \mathrm{g} / \mathrm{mL}$ 50SiNP (E).

Abbreviation: SiNP, silica nanoparticles.

activation induced by silica nanoparticles correlated well with nanoparticle-induced oxidative stress (Figure 2).

When activated, NF- $\mathrm{\kappa B}$ initiates the transcription of several genes involved in inflammation and coagulation. ${ }^{20,21}$ Here, we demonstrate that the amorphous silica nanoparticles induced upregulation of ICAM1, VCAM1, SELE, MMP9, COX2, F3, IL6, and IL8 gene expression in a size-, time-, and concentration-dependent manner, when compared with controls in the absence of nanoparticles. Three-hour exposure of primary HUVECs to a low concentration $(10 \mu \mathrm{g} / \mathrm{mL})$ of 10 SiNP did not induce upregulation of gene expression (Figure 5A). In contrast, a 7-hour exposure of primary HUVECs to an equal concentration of 10SiNP led to significant upregulation of ICAM1, VCAM1, SELE, COX2, F3, and IL8 gene expression 

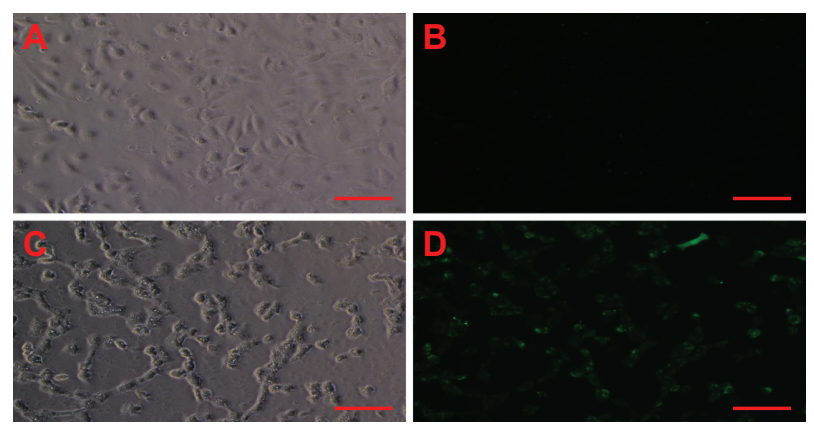

Figure 3 Amorphous SiNP induce oxidative/nitroxidative stress in primary human umbilical vein endothelial cells. As denoted by green fluorescence, exposure of cells to $10 \mu \mathrm{g} / \mathrm{mL}$ IOSiNP for I hour induced free radical production (D) when compared with the control in the absence of nanoparticles (B). The corresponding phasecontract micrographs of control (A) and treated (B) cells suggest cell death by necrosis induced by SiNP.

Note: Scale bars represent $100 \mu \mathrm{m}$.

Abbreviation: SiNP, silica nanoparticles.

(Figure 5B). Compared with 7 hours, after a 15-hour exposure of the cells to an equal concentration $(10 \mu \mathrm{g} / \mathrm{mL})$ of 10SiNP, a greater upregulation of ICAM1, VCAM1, SELE, MMP9, COX2, and F3 gene expression (Figure 5C-H), but also IL6 and IL8 (Figure 6A and B) was observed. We compared this nanoparticle-induced gene upregulation at various concentrations after a 15-hour exposure with the effects of larger nanoparticles (Figures 5 and 6). We found

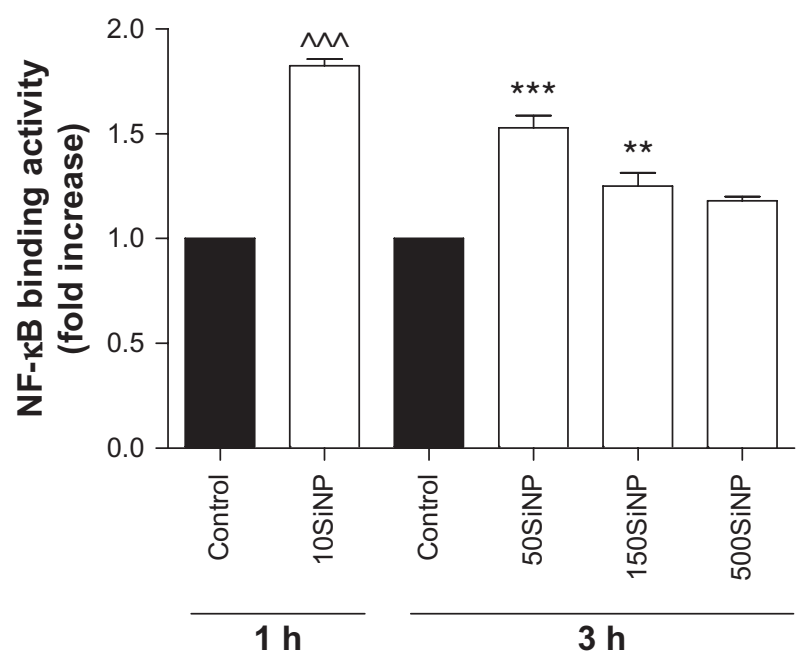

Figure 4 Amorphous SiNP induce NF- $\mathrm{B} B$ DNA binding activity in primary human umbilical vein endothelial cells. Exposure of cells to $10 \mu \mathrm{g} / \mathrm{mL}$ IOSiNP for I hour induced a significant increase of the NF-KB activity when compared with the control. Also, exposure of $50 \mu \mathrm{g} / \mathrm{mL}$ 50SiNP and I50SiNP, but not 500SiNP, for 3 hours induced increased transcription factor activity. The NF-KB DNA binding activity induced by each nanoparticle treatment is expressed relative to the control sample.

Notes: All values are presented as the mean \pm standard error of the mean of $\mathrm{n}=4$. By two-tailed Student's $t$-test, ${ }^{\wedge \wedge} \mathrm{p}<0.001$ compared with the control. By one-way analysis of variance, Tukey-Kramer multiple comparison test: $* * P<0.0$ I and $* * * P<0.001$ compared with the control. Filled bars correspond to cells which were not exposed to nanoparticles (control) and open bars to cells exposed to nanoparticles.

Abbreviation: SiNP, silica nanoparticles. that upregulation of gene expression was higher when the endothelial cells were exposed to increasingly higher concentrations of these nanoparticles, but lower when the size of these particles increased. Our real-time quantitative polymerase chain reaction studies (Figures 5 and 6) correlated directly with the unfavorable shift of the $[\mathrm{NO}] /\left[\mathrm{ONOO}^{-}\right]$ ratio derived from exposure of the endothelial cells to silica nanoparticles (Figure 2).

We also demonstrated that the use of the cell-permeable and irreversible proteasome inhibitor, lactacystin, that suppresses NF- $\kappa \mathrm{B}$ activity leading to downregulation of its target genes, ${ }^{38}$ significantly preventing upregulation of ICAM1, VCAM1, SELE, F3, and IL8 gene expression (Figure 7) induced by exposure of endothelial cells to amorphous silica nanoparticles. However, this effect was not observed for the MMP9, COX2, and IL6 genes (Figure 7).

Our data also show that exposure of primary HUVECs to amorphous silica nanoparticles resulted in increased release of IL6 and IL8 proteins into the cell culture supernatant in a size-dependent and concentration-dependent manner when compared with controls in the absence of nanoparticles (Figure 6C and D). Indeed, at $10 \mu \mathrm{g} / \mathrm{mL}, 10 \mathrm{SiNP}$ induced release of both cytokines. In contrast, an equal concentration of larger nanoparticles failed to increase such a release. However, increasing concentrations of 50SiNP, 150SiNP, and 500 SiNP resulted in significant release of both IL6 and IL8.

\section{Amorphous silica nanoparticles decrease viability of primary HUVECs}

Exposure of endothelial cells to amorphous silica nanoparticles led to increased cell death (Figure 8). The smallest nanoparticles $(10 \mathrm{~nm})$ induced the highest cytotoxicity in a time-dependent and concentration-dependent manner. Larger nanoparticles $(50,150$, and $500 \mathrm{~nm})$ showed very limited or no cytotoxicity, even after a 30-hour exposure.

\section{Discussion}

The novel findings of our study are that amorphous silica nanoparticles when internalized into the cytoplasm of primary HUVECs rapidly stimulated NO release. This was followed by a greater generation of $\mathrm{ONOO}^{-}$, leading to an unfavorably low $[\mathrm{NO}] /\left[\mathrm{ONOO}^{-}\right]$ratio that correlated well with SiNPinduced inflammatory responses in endothelial cells. Indeed, we observed that silica nanoparticles stimulated NF- $\mathrm{KB}$ DNA binding activity and upregulation of ICAM1, VCAM1, SELE, MMP9, COX2, F3, IL6, and IL8 gene expression. NF- $\kappa B$ activation also led to increased ICAM1, VCAM1, SELE, F3, and IL8 gene expression. The inflammatory 


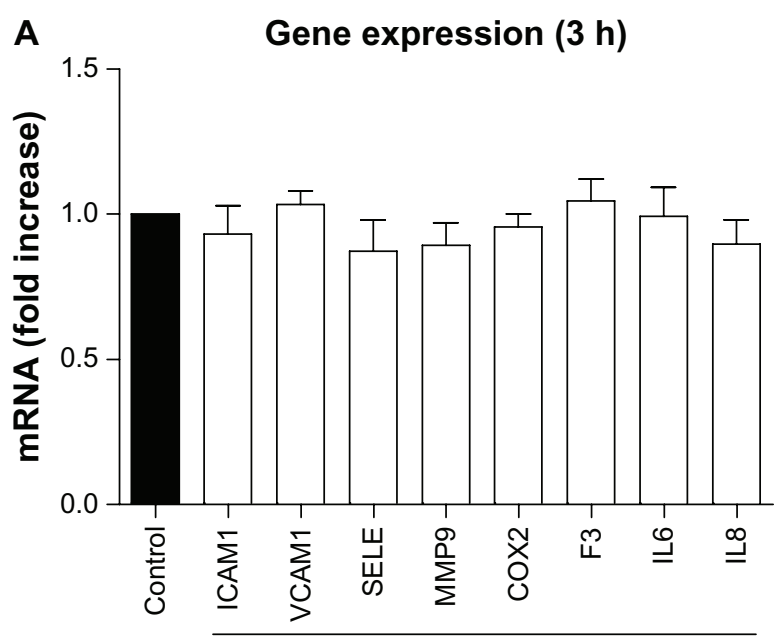

$10-\mu \mathrm{g} / \mathrm{mL} 10 \mathrm{SiNP}$

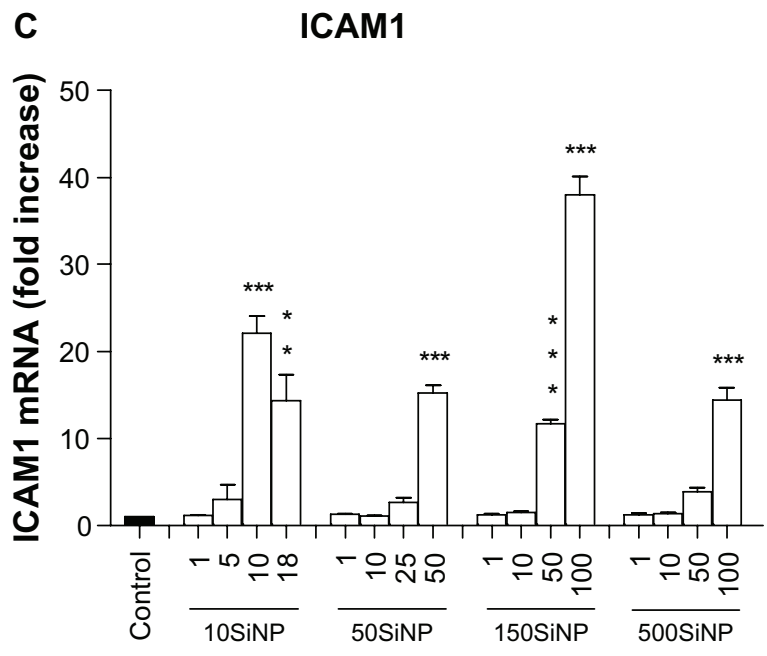

Nanoparticle concentration $(\mu \mathrm{g} / \mathrm{mL})$

E

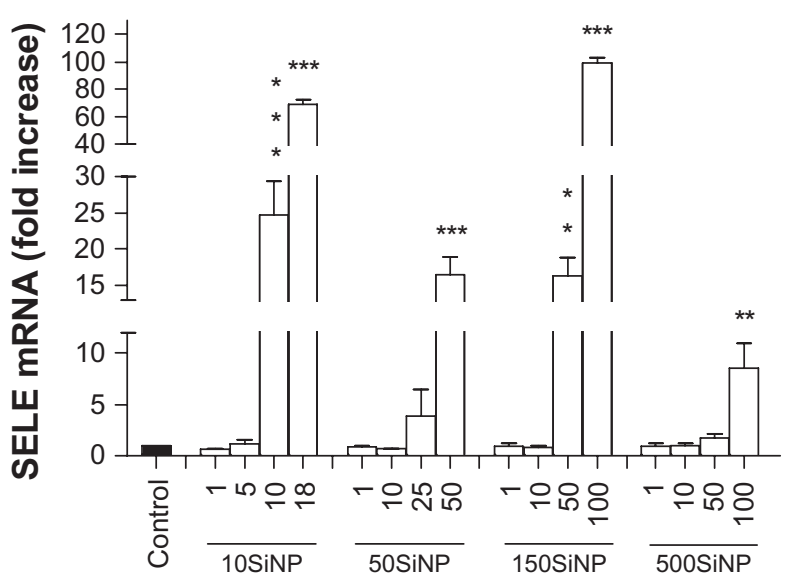

Nanoparticle concentration $(\mu \mathrm{g} / \mathrm{mL})$

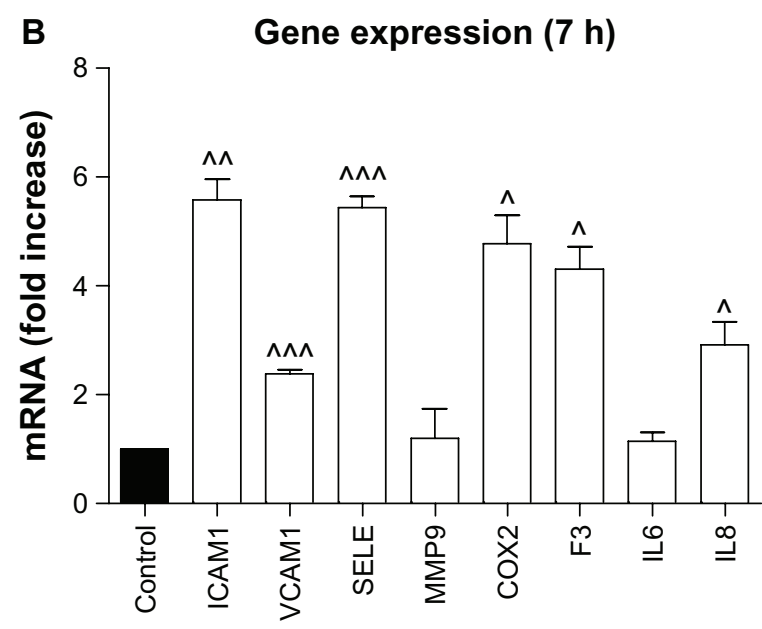

$10-\mu \mathrm{g} / \mathrm{mL} 10 \mathrm{SiNP}$

D

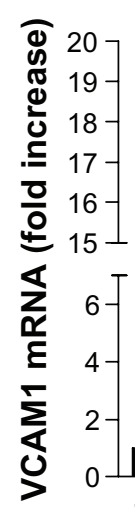

VCAM1

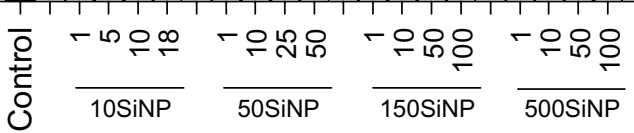

Nanoparticle concentration $(\mu \mathrm{g} / \mathrm{mL})$

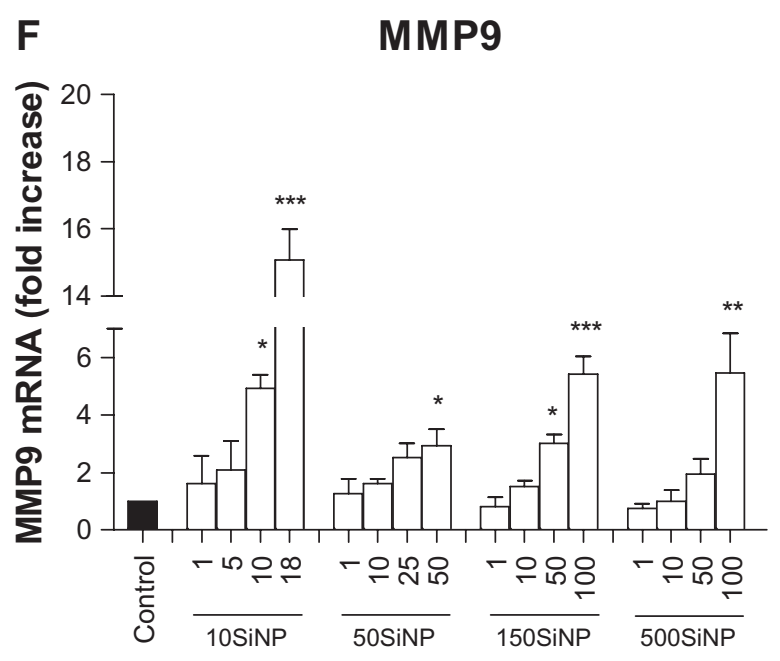

Nanoparticle concentration ( $\mu \mathrm{g} / \mathrm{mL})$

Figure 5 (Continued) 


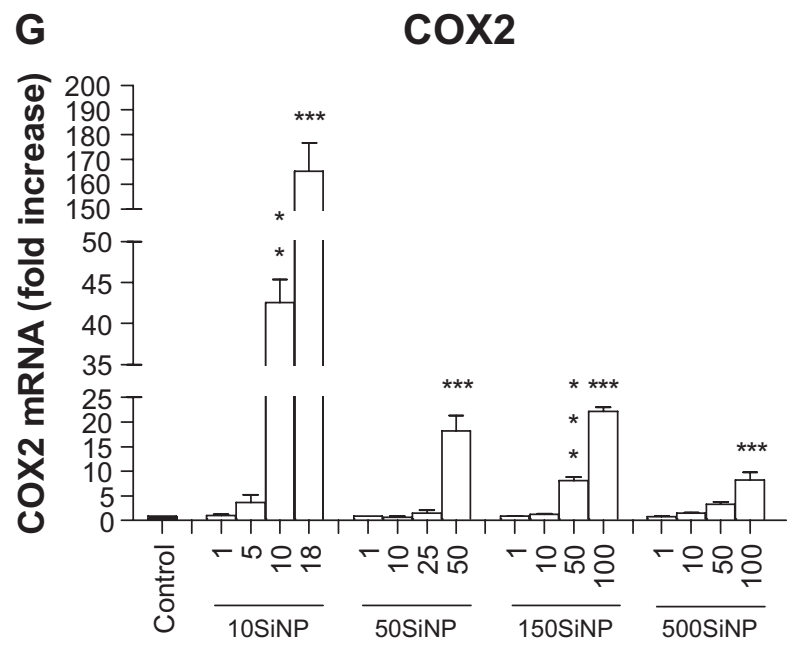

Nanoparticle concentration $(\mu \mathrm{g} / \mathrm{mL})$
H

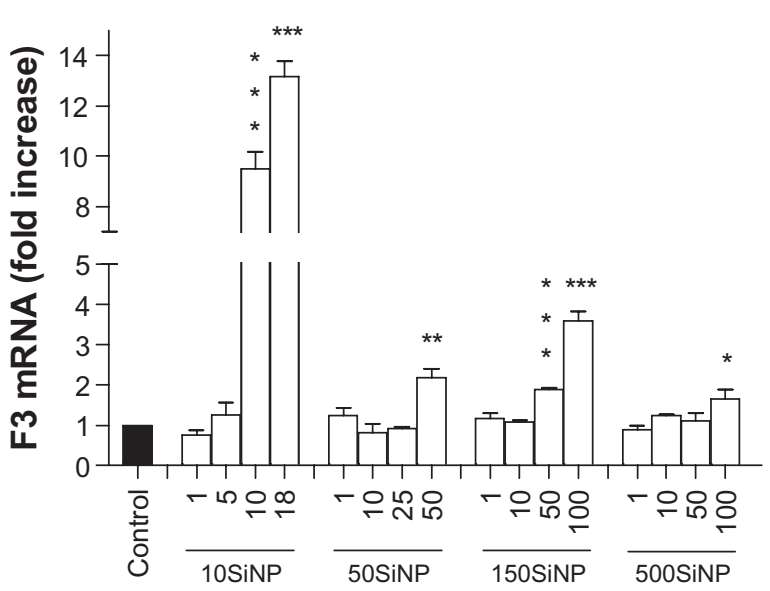

Nanoparticle concentration $(\mu \mathrm{g} / \mathrm{mL})$

Figure 5 Amorphous SiNP induce upregulation of endothelial gene expression of inflammatory mediators. Exposure of cells for $7 \mathrm{hours}(\mathbf{B})$ but not 3 hours (A) to $10 \mu \mathrm{g} / \mathrm{mL}$ IOSiNP upregulated gene expression as recorded by real-time quantitative polymerase chain reaction. The effect of these nanoparticles on gene expression at I5 hours was compared with that of larger nanoparticles $(\mathbf{C}-\mathbf{H})$. Silica nanoparticles upregulated gene expression in a size-, concentration-, and time-dependent manner. The expression

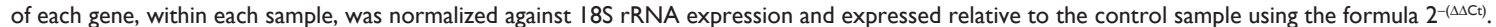

Notes: All values are the means \pm standard error of the mean of $n=4$. By two-tailed Student's $t$-test, ${ }^{\wedge} P<0.05$, ${ }^{\wedge} P<0.0$, and ${ }^{\wedge \wedge} P<0.00 \mathrm{I}$ compared with the control (A and B). By one-way analysis of variance, Tukey-Kramer multiple comparison test, $* P<0.05$, $* * P<0.01$, and $* * * P<0.001$ compared with the control $(\mathbf{C}-\mathbf{H})$. Filled bars correspond to cells not exposed to nanoparticles (control) and open bars to cells exposed to nanoparticles.

Abbreviations: SiNP, silica nanoparticles; ICAMI, intercellular adhesion molecule I; VCAMI, vascular cell adhesion molecule I; SELE, selectin E; MMP9, matrix metalloproteinase 9; IL6, interleukin-6; IL8, interleukin-8; COX, cyclo-oxygenase; F3, tissue factor.

reactions were associated with increased cell death. All of these inflammatory and cytotoxic effects were augmented with increased nanoparticle concentration, but were inversely proportional to the size of the silica nanoparticles. In fact, the smallest silica nanoparticles $(10 \mathrm{~nm})$ induced the most severe toxic effects on endothelial cells.

We showed that silica nanoparticles rapidly interacted with the plasma membrane and internalized into primary HUVECs. Nanoparticle uptake by cells may typically occur through nonspecific diffusion and/or endocytosis. ${ }^{39}$ It is increasingly recognized that particles of very different materials (eg, mesoporous silica ${ }^{40}$ ) can enter into the cell easily by endocytosis and accumulate in lysosomes. Our electron micrographs seem to indicate that endocytosis was involved in silica nanoparticle uptake by endothelial cells, since they were found mainly encapsulated in vesicles. However, nonencapsulated nanoparticles were also observed. This may indicate that the nanoparticles were internalized into these cells by mechanisms other than endocytosis or, most likely, the content of vesicles/lysosomes was released into the cytosol following membrane rupture.

Our transmission electron microscopic studies also show formation of silica nanoparticle agglomerates. A study by Nishikawa et $\mathrm{al}^{41}$ showed the involvement of endothelial caveolae (striated round structures with dimensions of 50-100 nm in both opening diameter and depth) in internalization of polysiloxane nanoparticles (diameter
10-100 nm). The polysiloxane nanoparticles were trapped in caveolae in the plasma membrane, internalized into the cytosol, and localized in the perinuclear region. Moreover, they also suggested the involvement of other pinocytosis pathways, including clathrin-coated pits (basket-like structures, 100-200 nm in diameter) and macropinocytosis, in the uptake of polysiloxane nanoparticles by endothelial cells. Amorphous silica nanoparticles may also internalize into HUVECs by caveolin-mediated endocytosis. However, some of the nanoparticle agglomerates we observed encapsulated into vesicles in the cytoplasm and interacting with the endothelial plasma membrane had dimensions much larger than the typical dimensions of caveolae. Nanoparticles have a high surface area-to-volume ratio, which increases in the opposite direction to size. This property allows adsorption of organic molecules and macromolecules, such as proteins. The adsorption of proteins at nanoparticle surfaces spontaneously occurs as soon as particles are placed in a protein solution. It has been shown that the "protein corona" thus formed may have fundamental significance for bionano interactions. ${ }^{34}$ Zeta potentials provide quantitative information on the stability of the particle. Higher zeta potential values (either positive or negative) indicate greater repulsion between particles, and therefore that the particles are more likely to remain dispersed. Therefore, the "protein corona", along with fluid characteristics, hydrophobicity, and zeta potentials, 


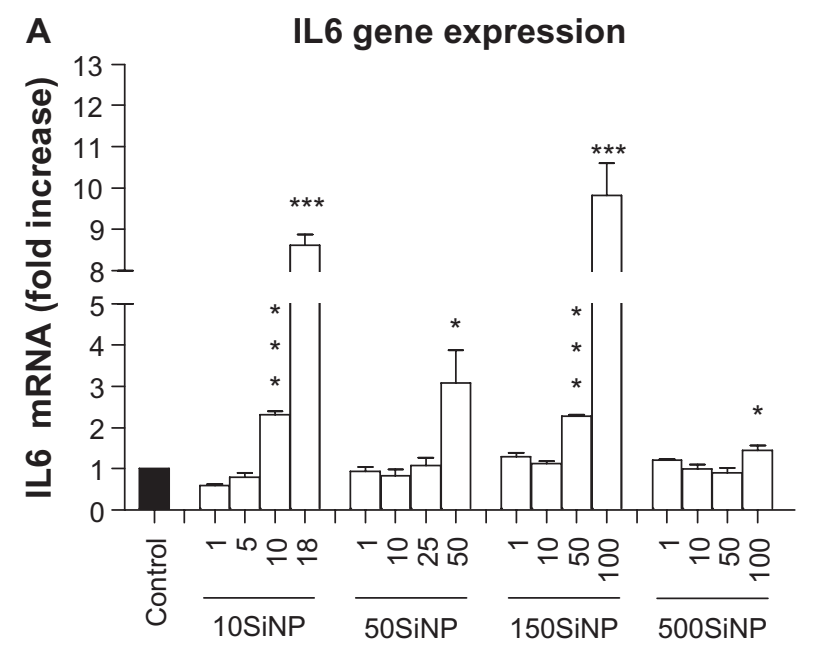

Nanoparticle concentration $(\mu \mathrm{g} / \mathrm{mL})$

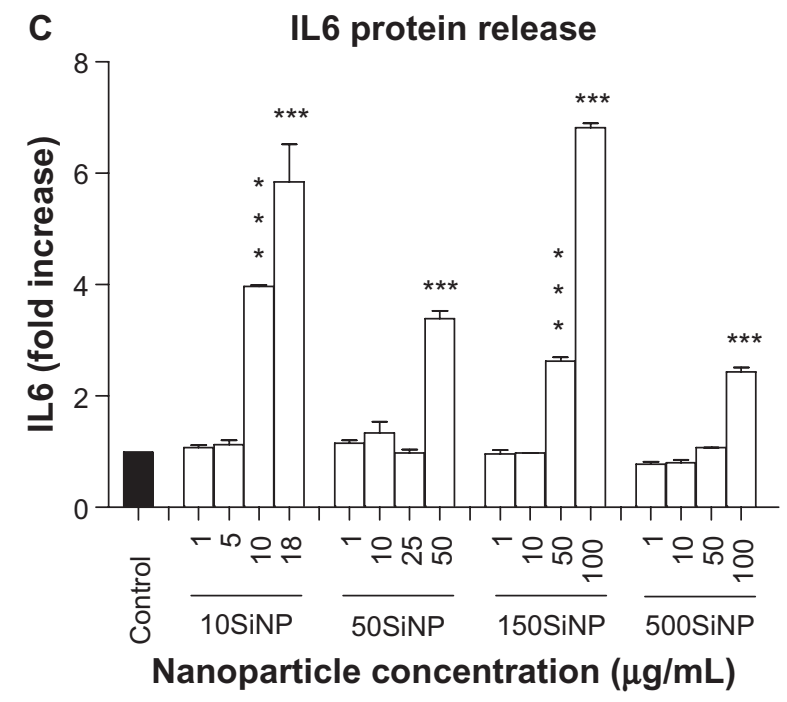

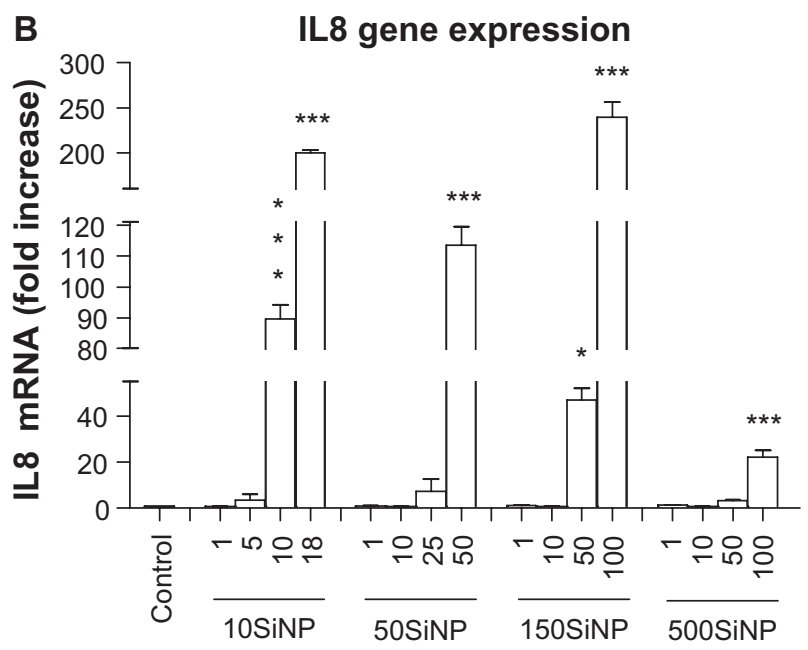

Nanoparticle concentration $(\mu \mathrm{g} / \mathrm{mL})$

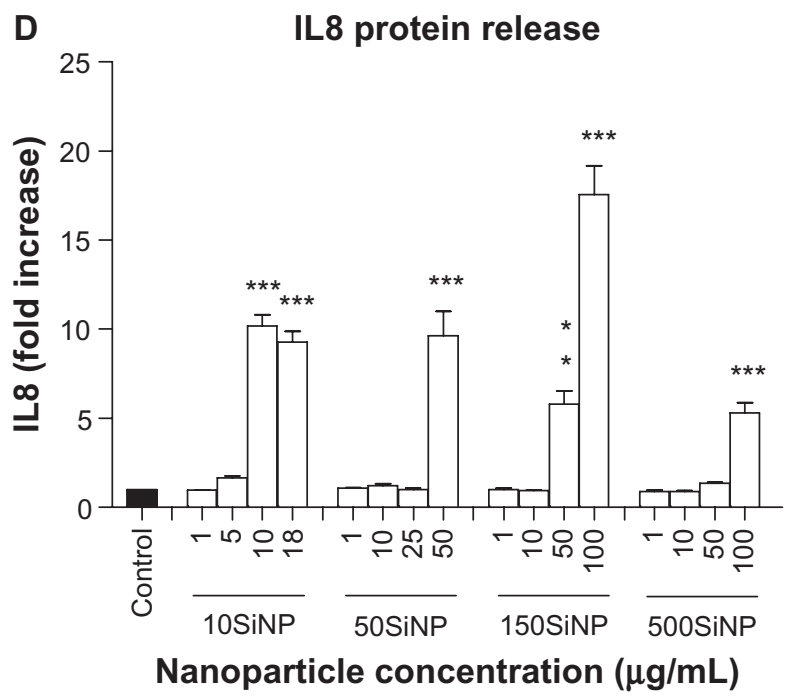

Figure 6 Amorphous SiNP induce upregulation of cytokine gene expression and cytokine release in primary human umbilical vein endothelial cells. A I5-hour exposure of primary human umbilical vein endothelial cells to nanoparticle-induced upregulation of IL6 (A) and IL8 (B) gene expression, as well as an increased cytokine (C IL6 and D IL8) release into the cell culture supernatant in a concentration-dependent and size-dependent manner. The expression of each gene, within each sample, was normalized against I8S rRNA expression and expressed relative to the control sample using the formula $2^{-(\Delta \Delta C t)}$. (A and $\left.\mathbf{B}\right)$. The cytokine release induced by each nanoparticle treatment is expressed relative to the control sample (C and $\mathbf{D}$ ).

Notes: All values are presented as the mean \pm standard error of the mean of $n=4$. By one-way analysis of variance, Tukey-Kramer multiple comparison test, $* P<0.05$, $* * P<0.01$, and $* * * P<0.00$ I compared with the control $(\mathbf{A}-\mathbf{D})$. Filled bars correspond to cells which were not exposed to nanoparticles (control) and open bars to cells exposed to nanoparticles.

Abbreviations: SiNP, silica nanoparticles; IL6, interleukin-6; IL8, interleukin-8.

can affect the formation of nanoparticle agglomerates in the biological environment. ${ }^{34,42}$

We suggest that the collision of silica nanoparticles with the endothelial plasma membrane and subsequent opening of calcium channels lead to uncoupling of endothelial nitric oxide synthase and generation of excessive amounts of peroxynitrite. There is convincing evidence that activation of stretch-activated calcium channels is linked to stimulation of endothelial nitric oxide synthase and rapid generation of $\mathrm{NO}$ and $\mathrm{ONOO}^{-}{ }^{43}$ The kinetics of the penetration of the cell membrane by silica nanoparticles most likely involves a flux of calcium ions into the cytoplasm. ${ }^{44}$ Therefore, silica nanoparticles are likely to stimulate calcium-dependent NO release in endothelial cells. The process of increased and prolonged NO production leads to depletion of enzymatic substrates and cofactors and, eventually, to uncoupling of endothelial nitric oxide synthase. ${ }^{45}$ Uncoupled endothelial nitric oxide synthase can generate superoxide,${ }^{16}$ which can rapidly react with $\mathrm{NO}$ to produce $\mathrm{ONOO}^{-}$and change the balance of $[\mathrm{NO}] /\left[\mathrm{ONOO}^{-}\right]$unfavorably. The ratio of the maximal $\mathrm{NO}$ to the maximal $\mathrm{ONOO}^{-}$concentrations was used in this study as an indicator of oxidative/nitroxidative 


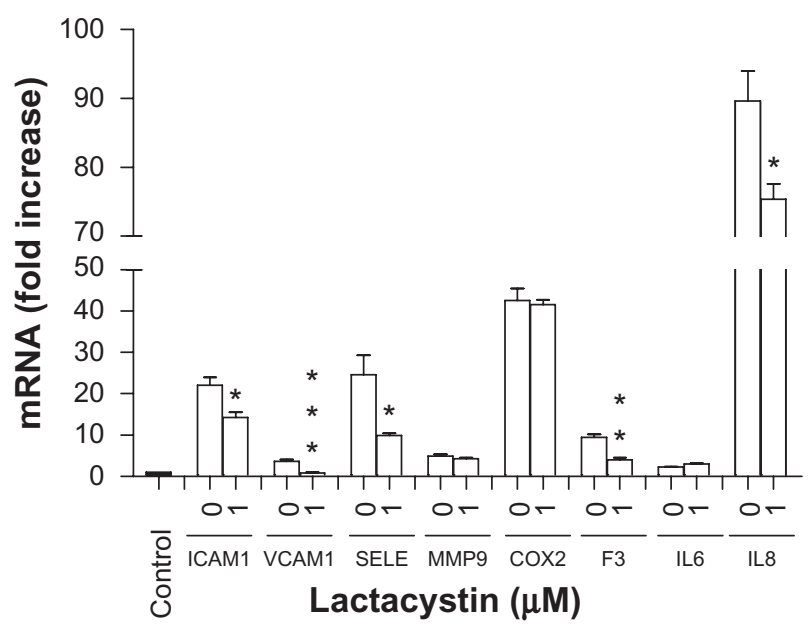

Figure 7 Amorphous SiNP induce upregulation of gene expression of inflammatory mediators by NF- $K B$ activation in primary human umbilical vein endothelial cells. Upregulation of gene expression of ICAMI, VCAMI, SELE, F3, and IL8 derived from exposure of cells to IOSiNP $(10 \mu \mathrm{g} / \mathrm{mL})$ was significantly lower in the present of lactacystin I $\mu \mathrm{M}$ indicating that NF- $\mathrm{KB}$ was involved in their expression. Expression of each gene, within each sample, was normalized against I8S rRNA expression and expressed relative to the control sample using the formula $2^{-(\Delta \Delta C t)}$.

Notes: Two-tailed Student's $t$-test: $* P<0.05$, $* * P<0.01$, $* * * P<0.001$ compared with controls in the presence of SiNP but in the absence of lactacystin. Filled bars correspond to cells which were not exposed to nanoparticles (control) and open bars to cells exposed to nanoparticles in the present (I $\mu \mathrm{M})$ or absence (0) of lactacystin.

Abbreviations: SiNP, silica nanoparticles; ICAMI, intercellular adhesion molecule I; VCAMI, vascular cell adhesion molecule I; SELE, selectin E; MMP9, matrix metalloproteinase 9; IL6, interleukin-6; IL8, interleukin-8; COX, cyclooxygenase; $\mathrm{F} 3$, tissue factor.

stress leading to endothelial dysfunction. At high levels of cytoprotective $\mathrm{NO}$ and/or low levels of cytotoxic $\mathrm{ONOO}^{-}$, this ratio is high $(>2.0)$ indicating coupled endothelial nitric oxide synthase and normal endothelial function. A low ratio $(<1.0)$ is associated with dysfunctional endothelium. An extremely low ratio $(<0.5)$ is indicative of severe uncoupled endothelial nitric oxide synthase and dysfunctional endothelium accompanied by high nitroxidative/oxidative stress. ${ }^{16,18}$ Our data show that exposure of endothelial cells to silica nanoparticles resulted in a very low $[\mathrm{NO}] /\left[\mathrm{ONOO}^{-}\right]$ratio, especially for $10 \mathrm{SiNP}(0.11 \pm 0.02$, at $10 \mu \mathrm{g} / \mathrm{mL})$, indicative of severe uncoupling of endothelial nitric oxide synthase, oxidative/nitroxidative stress, cell dysfunction, and necrosis. This high oxidative/nitroxidative stress reflected by high $\mathrm{ONOO}^{-}$production and a low $[\mathrm{NO}] /\left[\mathrm{ONOO}^{-}\right]$balance directly triggers a chain of reactions leading to endothelial inflammatory responses. ${ }^{19}$ This is evidenced by the ability of the amorphous silica nanoparticles to induce transcription factor activation (eg, NF- $\mathrm{KB}$ ) and eventually increased gene expression (eg, ICAM1, VCAM1, SELE, MMP9, COX2, F3, IL6, and IL8) and cytokine release (eg, IL6 and IL8).

We found that the amorphous silica nanoparticles induced increased endothelial NF- $\kappa$ B activity which was inversely proportional to the size of the nanoparticles. These data are also consistent with the ability of other nanoparticles to influence transcription factor activity; for instance, carbon black $(14 \mathrm{~nm})$ increases the activity of NF-KB and AP-1 in the A595 lung epithelial cell line in 1 hour. ${ }^{46} \mathrm{Also}$, crystalline silica has been shown to induce production of inflammatory mediators by activation of NF- $\mathrm{kB}$ in a RAW 264.7 mouse macrophage cell line. ${ }^{47}$ When activated, NF- $\kappa B$ initiates the transcription of several genes involved in inflammation and coagulation. ${ }^{20,21}$ Our data show that amorphous silica nanoparticle-induced upregulation of ICAM1, VCAM1, SELE, MMP9, COX2, F3, IL6, and IL8 gene expression in a fashion which was directly proportional to incubation time and nanoparticle concentration, but inversely proportional to nanoparticle size. However, use of lactacystin significantly prevented the expression of ICAM1, VCAM1, SELE, F3, and IL8. These observations indicate that other transcription factors (eg, AP-1) may also be involved in the endothelial inflammation induced by amorphous silica nanoparticles. Our data also show that exposure of primary HUVECs to amorphous silica nanoparticles led to increased cytokine release. Interestingly, upregulation of cytokine IL8 gene expression induced by silica nanoparticles, measured by real-time qualitative polymerase chain reaction, was always much higher than that of protein release measured by cytometric bead array. These differences may be explained by the fact that IL8 can be stored in Weibel-Palade bodies in the cytoplasm of endothelial cells. ${ }^{48}$ In contrast, gene upregulation of IL6 and protein release (fold-to-fold comparison) correlated well. Our data are in agreement with previous studies. For instance, it has been shown that engineered metal oxide particles upregulate ICAM1 and IL8 gene expression in human aortic endothelial cells. ${ }^{49}$ Further, silica nanoparticles induce the expression of IL8 in human dermal microvascular endothelial cells. ${ }^{50}$ Furthermore, oxidative stress-mediated $\mathrm{NF}-\kappa \mathrm{B}$ activation by silica nanoparticles has been suggested to increase expression of ICAM1, VCAM1, and SELE, as well as release of F3 and IL8 proteins in endothelial cells. ${ }^{37}$ The inflammatory responses induced by silica nanoparticles in endothelial cells reported here are similar to those induced in the endothelium in vivo by interleukin $1 \beta$ and tumor necrosis factor- $\alpha$ in the absence of infection. ${ }^{20}$ These responses correlated directly with an unfavorable shift of the $[\mathrm{NO}] /\left[\mathrm{ONOO}^{-}\right]$ ratio, leading to oxidative/nitroxidative stress arising from exposure of endothelial cells to silica nanoparticles.

We also demonstrated the ability of amorphous silica nanoparticles to decrease endothelial cell viability. These results were observed in direct proportion to incubation time and nanoparticle concentration, but inversely 

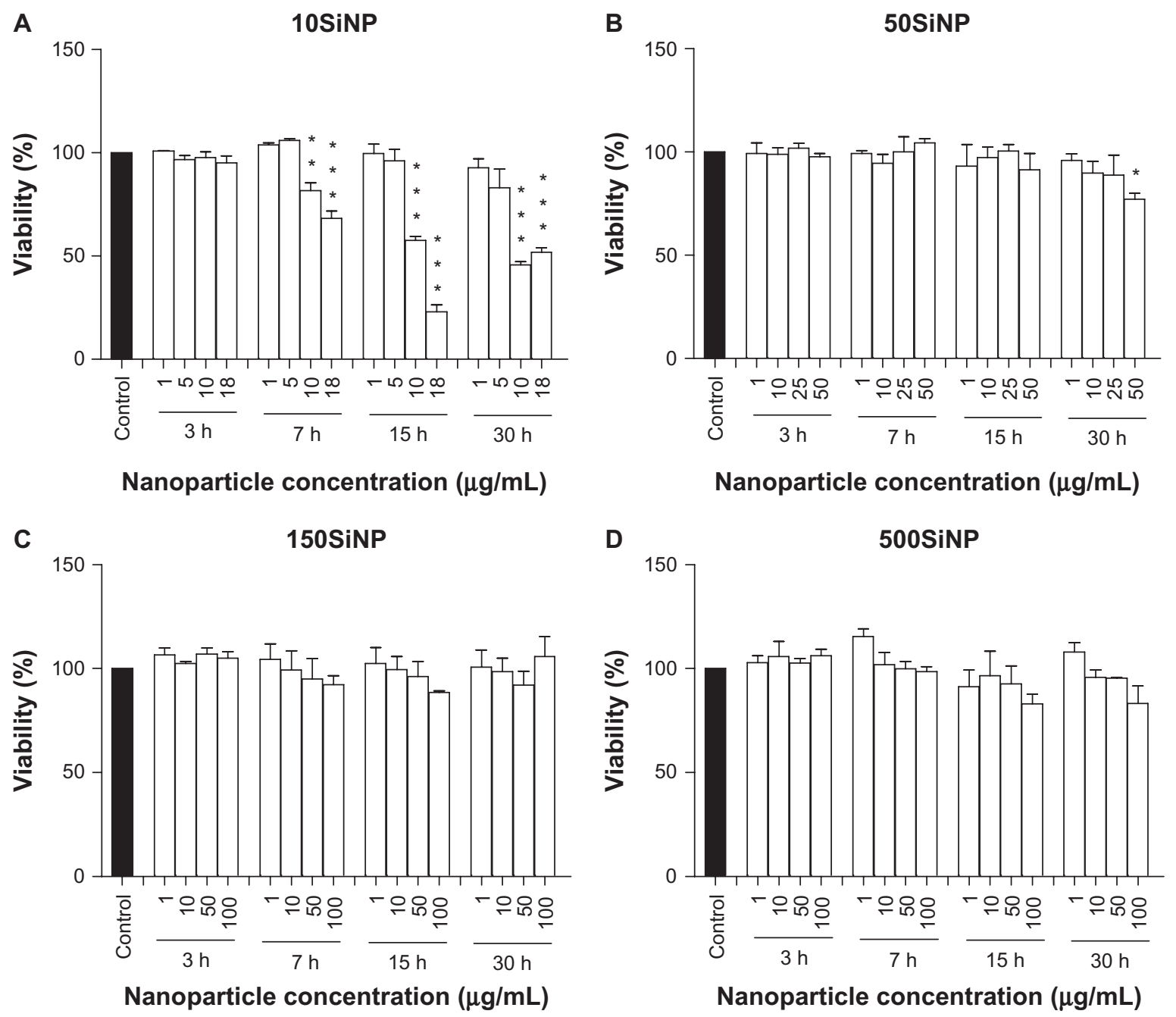

Figure 8 Amorphous SiNP induce cytotoxicity in primary human umbilical vein endothelial cells. Exposure of cells to IOSiNP (A) and 50SiNP (B) significantly decreased cell viability. In contrast, $150 \mathrm{SiNP}$ (C) and 500SiNP (D) failed to do so, even after a 30 -hour incubation at a $100 \mu \mathrm{g} / \mathrm{mL}$ nanoparticle concentration. Cell viability after each nanoparticle treatment was expressed relative to the control sample.

Notes: All values are presented as the mean \pm standard error of the mean of $n=4$. One-way analysis of variance, Tukey-Kramer multiple comparison test: $* P<0.05$, $* * P<0.01$ I, *** $P 0.001$ compared with the control. Filled bars correspond to cells which were not exposed to nanoparticles (control) and open bars to cells exposed to nanoparticles.

Abbreviation: SiNP, silica nanoparticles.

proportional to nanoparticle size. Napierska et al also showed size-dependent cytotoxicity of silica nanoparticles in EAHY926 cells. ${ }^{51}$

In summary, amorphous silica nanoparticles penetrated the plasma membrane of endothelial cells and stimulated rapid NO release. The rapid increase and prolonged production of NO lead to an uncoupling of endothelial nitric oxide synthase and generation of $\mathrm{ONOO}^{-}$, that eventually produced an overall decrease in the $[\mathrm{NO}] /\left[\mathrm{ONOO}^{-}\right]$ratio. An increase in the level of oxidative/nitroxidative stress induced by $\mathrm{ONOO}^{-}$decreased the bioavailability of cytoprotective $\mathrm{NO}$. The depleted $\mathrm{NO}$ and increased $\mathrm{ONOO}^{-}$production resulting in a low endothelial $[\mathrm{NO}] /\left[\mathrm{ONOO}^{-}\right]$balance was inversely proportional to nanoparticle size, but in direct correlation with particle concentration, and inflammatory and cytotoxic responses. This article provides for the first time quantitative and qualitative data linking the deleterious effects of silica nanoparticles directly to dysfunction of endothelial nitric oxide synthase and overproduction of $\mathrm{ONOO}^{-}$. Amorphous silica nanoparticles have toxic effects on endothelial cells and may impair vascular homeostasis. These effects are especially severe for silica nanoparticles smaller than $50 \mathrm{~nm}$.

\section{Acknowledgments}

This project was funded by a Science Foundation Ireland grant to MWR and a Trinity College Dublin award to JJC. The authors would like to thank Lorraine O'Driscoll, Lidia 
Tajber, and Neal Leddy for their technical assistance. CM is a Science Foundation Ireland Stokes Lecturer.

\section{Disclosure}

The authors report no conflicts of interest in this work.

\section{References}

1. Kumar R, Roy I, Ohulchanskky TY, et al. In vivo biodistribution and clearance studies using multimodal organically modified silica nanoparticles. ACS Nano. 2010;4(2):699-708.

2. Selvan ST, Tan TT, Yi DK, Jana NR. Functional and multifunctional nanoparticles for bioimaging and biosensing. Langmuir. 2010;26(14): 11631-11641.

3. Chen Z, Meng H, Xing G, et al. Age-related differences in pulmonary and cardiovascular responses to $\mathrm{SiO}_{2}$ nanoparticle inhalation: nanotoxicity has susceptible population. Environ Sci Technol. 2008;42(23): 8985-8992.

4. Napierska D, Thomassen LC, Lison D, Martens JA, Hoet PH. The nanosilica hazard: another variable entity. Part Fibre Toxicol. 2010; $7(1): 39$.

5. Barnes CA, Elsaesser A, Arkusz J, et al. Reproducible comet assay of amorphous silica nanoparticles detects no genotoxicity. Nano Lett. 2008;8(9):3069-3074.

6. Nabeshi H, Yoshikawa T, Matsuyama K, et al. Amorphous nanosilica induce endocytosis-dependent ROS generation and DNA damage in human keratinocytes. Part Fibre Toxicol. 2011;8:1.

7. Park MV, Verharen HW, Zwart E, et al. Genotoxicity evaluation of amorphous silica nanoparticles of different sizes using the micronucleus and the plasmid lacZ gene mutation assay. Nanotoxicology. 2011;5: 168-181.

8. Jaffe EA, Nachman RL, Becker CG, Minick CR. Culture of human endothelial cells derived from umbilical veins. Identification by morphologic and immunologic criteria. J Clin Invest. 1973;52(11): 2745-2756.

9. Pacher P, Beckman JS, Liaudet L. Nitric oxide and peroxynitrite in health and disease. Physiol Rev. 2007;87(1):315-424.

10. Malinski T, Radomski MW, Taha Z, Moncada S. Direct electrochemical measurement of nitric oxide released from human platelets. Biochem Biophys Res Commun. 1993;194(2):960-965.

11. Palmer RM, Ferrige AG, Moncada S. Nitric oxide release accounts for the biological activity of endothelium-derived relaxing factor. Nature. 1987;327(6122):524-526.

12. Radomski MW, Palmer RM, Moncada S. The anti-aggregating properties of vascular endothelium: interactions between prostacyclin and nitric oxide. Br J Pharmacol. 1987;92(3):639-646.

13. Radomski MW, Palmer RM, Moncada S. An L-arginine/nitric oxide pathway present in human platelets regulates aggregation. Proc Natl Acad Sci U S A. 1990;87(13):5193-5197.

14. Alonso D, Radomski MW. Nitric oxide, platelet function, myocardial infarction and reperfusion therapies. Heart Fail Rev. 2003;8(1): $47-54$.

15. Beckman JS, Beckman TW, Chen J, Marshall PA, Freeman BA. Apparent hydroxyl radical production by peroxynitrite: implications for endothelial injury from nitric oxide and superoxide. Proc Natl Acad Sci U S A. 1990;87(4):1620-1624.

16. Kalinowski L, Dobrucki IT, Malinski T. Race-specific differences in endothelial function: predisposition of African Americans to vascular diseases. Circulation. 2004;109(21):2511-2517.

17. Villa LM, Salas E, Darley-Usmar VM, Radomski MW, Moncada S. Peroxynitrite induces both vasodilatation and impaired vascular relaxation in the isolated perfused rat heart. Proc Natl Acad Sci U S A. 1994;91(26):12383-12387.

18. Heeba G, Hassan MK, Khalifa M, Malinski T. Adverse balance of nitric oxide/peroxynitrite in the dysfunctional endothelium can be reversed by statins. J Cardiovasc Pharmacol. 2007;50(4):391-398.
19. Tumur Z, Shimizu H, Enomoto A, Miyazaki H, Niwa T. Indoxyl sulfate upregulates expression of ICAM-1 and MCP-1 by oxidative stressinduced NF-kappaB activation. Am J Nephrol. 2010;31(5):435-441.

20. Pober JS, Sessa WC. Evolving functions of endothelial cells in inflammation. Nat Rev Immunol. 2007;7(10):803-815.

21. Pahl HL. Activators and target genes of Rel/NF-kappaB transcription factors. Oncogene. 1999;18(49):6853-6866.

22. Lawson C, Wolf S. ICAM-1 signaling in endothelial cells. Pharmacol Rep. 2009;61(1):22-32.

23. Pepinsky B, Hession C, Chen LL, et al. Structure/function studies on vascular cell adhesion molecule-1. J Biol Chem. 1992;267(25): 17820-17826.

24. Graves BJ, Crowther RL, Chandran C, et al. Insight into E-selectin/ ligand interaction from the crystal structure and mutagenesis of the lec/EGF domains. Nature. 1994;367(6463):532-538.

25. Sternlicht MD, Werb Z. How matrix metalloproteinases regulate cell behavior. Annu Rev Cell Dev Biol. 2001;17:463-516.

26. Visse R, Nagase H. Matrix metalloproteinases and tissue inhibitors of metalloproteinases: structure, function, and biochemistry. Circ Res. 2003;92(8):827-839.

27. Steffel J, Luscher TF, Tanner FC. Tissue factor in cardiovascular diseases: molecular mechanisms and clinical implications. Circulation. 2006;113(5):722-731.

28. Romano M, Sironi M, Toniatti C, et al. Role of IL-6 and its soluble receptor in induction of chemokines and leukocyte recruitment. Immunity. 1997;6(3):315-325.

29. Sprague AH, Khalil RA. Inflammatory cytokines in vascular dysfunction and vascular disease. Biochem Pharmacol. 2009;78(6):539-552.

30. Malinski T, Taha $Z$. Nitric oxide release from a single cell measured in situ by a porphyrinic-based microsensor. Nature. 1992;358(6388): 676-678.

31. Brovkovych V, Patton S, Brovkovych S, Kiechle F, Huk I, Malinski T. In situ measurement of nitric oxide, superoxide and peroxynitrite during endotoxemia. J Physiol Pharmacol. 1997;48(4):633-644.

32. Livak KJ, Schmittgen TD. Analysis of relative gene expression data using real-time quantitative PCR and the 2-delta delta $\mathrm{C}(\mathrm{T})$ method. Methods. 2001;25(4):402-408.

33. Murdock RC, Braydich-Stolle L, Schrand AM, Schlager JJ, Hussain SM. Characterization of nanomaterial dispersion in solution prior to in vitro exposure using dynamic light scattering technique. Toxicol Sci. 2008; 101(2):239-253.

34. Lundqvist M, Stigler J, Elia G, Lynch I, Cedervall T, Dawson KA. Nanoparticle size and surface properties determine the protein corona with possible implications for biological impacts. Proc Natl Acad Sci U S A. 2008;105(38):14265-14270.

35. Li N, Xia T, Nel AE. The role of oxidative stress in ambient particulate matter-induced lung diseases and its implications in the toxicity of engineered nanoparticles. Free Radic Biol Med. 2008;44(9): 1689-1699.

36. Hussain S, Thomassen LC, Ferecatu I, et al. Carbon black and titanium dioxide nanoparticles elicit distinct apoptotic pathways in bronchial epithelial cells. Part Fibre Toxicol. 2010;7:10.

37. Liu X, Sun J. Endothelial cell dysfunction induced by silica nanoparticles through oxidative stress via JNK/P53 and NF-kappaB pathways. Biomaterials. 2010;31(32):8198-8209.

38. Shah JJ, Orlowski RZ. Proteasome inhibitors in the treatment of multiple myeloma. Leukemia. 2009;23(11):1964-1979.

39. Chavanpatil MD, Khdair A, Panyam J. Nanoparticles for cellular drug delivery: mechanisms and factors influencing delivery. $J$ Nanosci Nanotechnol. 2006;6(9-10):2651-2663.

40. He Q, Zhang Z, Gao Y, Shi J, Li Y. Intracellular localization and cytotoxicity of spherical mesoporous silica nano- and microparticles. Small. 2009;5(23):2722-2729.

41. Nishikawa T, Iwakiri N, Kaneko Y, et al. Nitric oxide release in human aortic endothelial cells mediated by delivery of amphiphilic polysiloxane nanoparticles to caveolae. Biomacromolecules. 2009;10(8): 2074-2085. 
42. Thomassen LC, Aerts A, Rabolli V, et al. Synthesis and characterization of stable monodisperse silica nanoparticle sols for in vitro cytotoxicity testing. Langmuir. 2010;26(1):328-335.

43. Dyachenko V, Rueckschloss U, Isenberg G. Modulation of cardiac mechanosensitive ion channels involves superoxide, nitric oxide and peroxynitrite. Cell Calcium. 2009;45(1):55-64.

44. Gelderman MP, Simakova O, Clogston JD, et al. Adverse effects of fullerenes on endothelial cells: fullerenol $\mathrm{C} 60(\mathrm{OH}) 24$ induced tissue factor and ICAM-I membrane expression and apoptosis in vitro. Int $J$ Nanomedicine. 2008;3(1):59-68.

45. Huk I, Nanobashvili J, Neumayer C, et al. L-arginine treatment alters the kinetics of nitric oxide and superoxide release and reduces ischemia/reperfusion injury in skeletal muscle. Circulation. 1997;96(2): 667-675.

46. Mroz RM, Schins RP, Li H, Drost EM, Macnee W, Donaldson K Nanoparticle carbon black driven DNA damage induces growth arrest and AP-1 and NFkappaB DNA binding in lung epithelial A549 cell line. J Physiol Pharmacol. 2007;58 Suppl 5(Pt 2):461-470.
47. Chen F, Sun SC, Kuh DC, Gaydos LJ, Demers LM. Essential role of NF-kappa B activation in silica-induced inflammatory mediator production in macrophages. Biochem Biophys Res Commun. 1995; 214(3):985-992.

48. RotA, Hub E, Middleton J, et al. Some aspects of IL-8 pathophysiology. III: Chemokine interaction with endothelial cells. J Leukoc Biol. 1996;59(1): 39-44.

49. Gojova A, Guo B, Kota RS, Rutledge JC, Kennedy IM, Barakat AI. Induction of inflammation in vascular endothelial cells by metal oxide nanoparticles: effect of particle composition. Environ Health Perspect. 2007;115(3):403-409

50. Peters K, Unger RE, Kirkpatrick CJ, Gatti AM, Monari E. Effects of nano-scaled particles on endothelial cell function in vitro: studies on viability, proliferation and inflammation. JMater Sci Mater Med. 2004; 15(4):321-325.

51. Napierska D, Thomassen LC, Rabolli V, et al. Size-dependent cytotoxicity of monodisperse silica nanoparticles in human endothelial cells. Small. 2009;5(7):846-853.
International Journal of Nanomedicine

\section{Publish your work in this journal}

The International Journal of Nanomedicine is an international, peerreviewed journal focusing on the application of nanotechnology in diagnostics, therapeutics, and drug delivery systems throughout the biomedical field. This journal is indexed on PubMed Central,

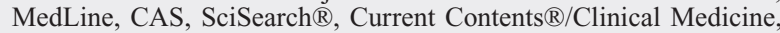

\section{Dovepress}

Journal Citation Reports/Science Edition, EMBase, Scopus and the Elsevier Bibliographic databases. The manuscript management system is completely online and includes a very quick and fair peer-review system, which is all easy to use. Visit http://www.dovepress.com/ testimonials.php to read real quotes from published authors 